\title{
PENGARUH MODEL PEMBELAJARAN GENERATIF DISERTAI MEDIA RIIL DAN MEDIA VIRTUIL DITINJAU DARI GAYA BELAJAR
}

\author{
M. Soeprijadi Djoko Laksana
}

\begin{abstract}
Abstrak
Tujuan penelitian ini untuk mengetahui pengaruh model pembelajaran generatif melalui media riil dan media virtuil, gaya belajar dan interaksinya terhadap prestasi belajar ranah kognitif, afektif, dan psikomotorik mahasiswa. Penelitian ini menggunakan metode eksperimen dengan desain faktorial $2 \times 2$. Populasi penelitian adalah seluruh mahasiswa Prodi Biologi semester I IKIP PGRI Madiun Tahun Akademik 2012/2013. Sampel diperoleh dengan teknik sampling jenuh terdiri dari 2 kelas. Pengumpulan data menggunakan teknik tes dan non tes.Data dianalisis menggunakan anava dua jalan dengan SPSS 18. Uji validitas instrumen menggunakan korelasi product moment Karl Pearson dan uji reliabilitas menggunakan persamaan Kuder Richardson. Berdasarkan hasil analisis data disimpulkan: 1) ada pengaruh penggunaan model pembelajaran generatif terhadap prestasi belajar kognitif, afektif, dan psikomotor mahasiswa; 2) ada pengaruh gaya belajar terhadap prestasi kognitif, afektif, dan psikomotor mahasiswa; 3) tidak ada interaksi antara model pembelajaran generatif melalui media riil dan virtual dengan gaya belajar terhadap prestasi belajar mahasiswa pada aspek kognitif, afektif dan psikomotor;
\end{abstract}

Kata Kunci : Model Pembelajaran Generatif, Media Riil, Media Virtuil, Gaya Belajar

\section{Pendahuluan}

Pendidikan merupakan penentu arah perjalanan suatu bangsa, karena masa depan suatu bangsa akan sangat ditentukan oleh kualitas pendidikannya. Dengan pendidikan diharapkan mampu memberikan jalan pemecahan masalah bagi pembangunan yakni tersedianya sumber daya manusia yang berkualitas. Sumber daya manusia yang berkualitas akan mampu mengantisipasi setiap perubahan yang terjadi dengan cepat dan memiliki kemampuan penyesuaian diri atas kecakapan untuk menghadapi segala bentuk perubahan tersebut. Hanya dengan pendidikan berkualitas akan dihasilkan sumber daya manusia yang berkualitas. Hal ini sesuai dengan penjelasan Undang-undang tentang Sistem Pendidikan Nasional dan juga Peraturan Pemerintah No. 19 tahun 2005 tentang Standar Nasional Pendidikan, yang menyatakan bahwa visi pendidikan nasional adalah mewujudkan sistem pendidikan sebagai pranata sosial yang kuat dan berwibawa untuk memberdayakan semua warga negara Indonesia agar berkembang menjadi manusia yang berkualitas sehingga mampu dan proaktif menjawab tantangan zaman yang selalu berubah. Konsep "pendidikan untuk semua" mempunyai makna bahwa semua warga negara mempunyai hak untuk memperoleh pendidikan yang baik, juga mempunyai kewajiban untuk membangun pendidikan nasional yang bermutu (Depdiknas, 2005).

Upaya peningkatan kualitas perguruan tinggi, ketersediaan sumber daya yang baik dan memadai, merupakan persyaratan yang diperlukan, tetapi persyaratan itu belum cukup, oleh karena itu konsep pendidikan lebih diarahkan pada proses pembelajaran. Semua ini diperlukan dalam rangka bersaing menuju era globalisasi. Dalam hal ini pendidikan tidak hanya sebagai pentransfer ilmu tetapi memiliki peran yang lebih besar. Dengan peran pendidikan yang semakin luas, mahasiswa ditempatkan sebagai pusat belajar yang secara aktif di kelas dalam menyampaikan ide atau gagasan, argumentasi, mengomentari sebuah topik atau materi kuliah yang disampaikan.

Lembaga pendidikan tinggi perlu melakukan perubahan besar pada sistem pendidikan, dengan demikian akan menghasilkan lulusan yang jauh lebih berkualitas. Model pembelajaran dengan cara dosen menjelaskan dan memberi materi dalam kelas kepada mahasiswa adalah bentuk pembelajaran model lama, dalam hal ini perlu lagi dosen untuk merubah pola pikir merasa jauh lebih pintar dari mahasiswa dan pusat segala ilmu. Penting bagi dosen untuk menciptakan pengalaman menyenangkan bagi mahasiswa ketika belajar.Perkuliahan jangan dianggap sebagai satusatunya sumber pengetahuan, disamping itu dosen juga harus memiliki kompetensi yang baik untuk dapat menciptakan ruang belajar yang jauh lebih efektif dan lebih fleksibel, partisipatif dan akomodatif serta lebih kreatif.

Institut Keguruan dan Ilmu Pendidikan (IKIP) merupakan salah satu lembaga pendidikan yang secara formal bertanggung jawab mempersiapkan mahasiswa yang berorientasi pada masa depan, yaitu mahasiswa yang mampu memecahkan masalah, menghadapi situasi, membuat keputusan dan mengimplementasikannya untuk menghadapi masalah dalam kehidupan sehari-hari (Lili Maysari, 2010). Berdasarkan profil IKIP PGRI Madiun, tugas utama IKIP PGRI Madiun adalah mempersiapkan calon guru yang profesional, demokratis, mandiri, mampu memecahkan masalah yang dihadapinya baik dalam kehidupam bermasyarakat maupun di dunia kerja nantinya serta siap berkompetisi dalam era global. Namun kenyataannya mahasiswa cenderung kurang kreatif dan mandiri dalam menyelesaikan masalah ketika mereka dihadapkan pada suatu masalah.Hal ini dikarenakan pembelajaran masih terfokus pada dosen/tenaga pendidik saja. IKIP PGRI Madiun merupakan satu-satunya Sekolah Tinggi Swasta di Kotamadya Madiun yang mempunyai Fakultas Pendidikan MIPA dan menyelenggarakan Program 
Studi Pendidikan Biologi. Untuk itu Program Studi Pendidikan Biologi bertanggung jawab menghasilkan tenaga pendidik yang profesional dan kompeten dalam mengajar di satuan pendidikan tempat mereka bekerja nantinya.Berdasarkan pengalaman Tabel 1. Nilai Akhir Mata Kuliah Biologi Umum IKIP PGR

\begin{tabular}{ccc}
\hline No & Tahun Akademik & Nilai Rata-rata \\
\hline 1 & $2009 / 2010$ & 66,30 \\
2 & $2010 / 2011$ & 67,20 \\
3 & $2011 / 2012$ & 70,15 \\
\hline
\end{tabular}

Berdasarkan tabel di atas nilai rata-rata belum memenuhi kriteria memuaskan. Hal ini tentu saja pada akhirnya akan mempengaruhi kualitas out put lulusan dan akan menyebabkan mahasiswa tidak mampu mengaplikasikan ilmu yang didapatkan secara menyeluruh dalam kehidupan sehari-hari ataupun dalam kegiatan profesionalnya sebagai guru nantinya. IKIP PGRI Madiun sebagai lembaga yang memiliki tujuan menghasilkan tenaga pengajar yang profesional, yang pada akhirnya tidak akan dapat mencapai tujuan ini. Oleh karena itu perlu diterapkan suatu pendekatan/ model pembelajaran yang dapat mendorong peningkatan kemampuan berpikir tingkat tinggi (Higher Order Thinking Skills). Konstruktivisme merupakan suatu rujukan belajar yang memandang bahwa pengetahuan harus dikonstruksi sendiri oleh subyek yang sedang belajar, sehingga merupakan proses aktif yang dilakukan oleh mahasiswa. Salahsatu model pembelajaran yang berlandaskan konstruktivisme adalah model pembelajaran generatif atau generative learning.

Model pembelajaran generatif ini pertama kali dikembangkan oleh Obsorne \& Wittrock pada tahun 1985. Esensi pembelajaran generatif bertumpu pada pemahaman bahwa pikiran (otak manusia) bukanlah penerima informasi secara pasif, melainkan aktif, mengkonstruksi dan menafsirkan informasi serta mengambil kesimpulan. Dinyatakan bahwa pembelajaran generatif merupakan cara yang baik untuk mengembangkan pola berpikir mahasiswa. Dalam pembelajaran generatif,guru hanya berperan sebagai fasilitator dan mediator yang mendorong mahasiswa untuk melakukan sendiri aktivitas penggalian dan penemuan konsep serta mengarahkan mahasiswa ke konsep yang benar. Dalam proses belajar dan pembelajaran selain diperlukan suatu model pembelajaran yang tepat juga diperlukan suatu media pembelajaran. Media pembelajaran adalah suatu alat atau sarana untuk menyampaikan materi pembelajaran.Pembelajaran Biologi akan lebih bermakna apabila dosen bisa memanfaatkan lingkungan alam sekitar sebagai media pembelajaran yang disebut sebagai media riil, yang dapat diamati dan diobservasi oleh mahasiswa. Media riil disamping dapat diterapkan dengan memanfaatkan lingkungan, juga dapat dilakukan dengan cara membawa benda-benda riil kedalam ruang kuliah untuk dijadikan sebagai media
(Sumber :Data Nilai Akhir Biologi)

empiris selama ini,prestasi belajar mata kuliah Biologi Umum mahasiswa Program Pendidikan Biologi di IKIP PGRI Madiun, belum optimal. Hal ini terlihat dari prestasi belajar selama peneliti mengajar di Prodi tersebut. pembelajaran. Apabila hal ini tidak memungkinkan,
maka dosen dapat berkreasi dengan membuat barang tiruan atau replikanya.Selain media riil dikenal juga media virtuil sebagai media pembelajaran. Media virtuil dapat berupa gambar-gambar, foto-foto dan film-film yang ditampilkan pada proses belajar dan pembelajaran.

Carin and Sund (dalam Wenno, 2008) pembelajaran biologi sebagai bagian dari sains, harus mengacu pada tiga aspek yaitu: produk, proses, dan sikap. Sains sebagai konten atau produk berarti bahwa dalam sains terdapat fakta-fakta, hukum-hukum, prinsip-prinsip dan teori-teori yang sudah diterima kebenarannya. Sains sebagai proses atau metode berarti sains merupakan suatu proses atau metode untuk mendapatkan pengetahuan. Selain sebagai produk dan proses, sains juga merupakan sikap, artinya bahwa dalam sains terkandung sikap seperti tekun, terbuka, jujur, dan obyektif.

Banyaknya pelaksanaan pembelajaran Biologi yang tidak memperhatikan hakekat biologi menyebabkan proses pembelajaran berjalan secara konvensional, tidak mempertimbangkan pendekatandan metode yang digunakan sehingga proses pembelajaran berlangsung secara monoton, kurang menarik dan kurang memacu motivasi belajar mahasiswa. Mahasiswa tidak diajak belajar penemuan atau pengamatan lagsung di lapangan/alam ataupun dilaboratorium, sebagai manifestasi biologi yang mempelajari seluk beluk kehidupan dan interaksinya dengan lingkungan, sehingga pembelajaran kurang bermakna dan konsep-konsep yang diterima akan mudah dilupakan.

Keberhasilan pembelajaran juga disebabkan oleh faktor intrinsik mahasiswa. Ada banyak faktor intrinsik mahasiswa, diantaranya kemampuan awal, kreativitas, gaya belajar dan sebagainya, namun dalam penelitian ini, faktor intrinsik yang paling berpengaruh dalam pembelajaran adalah gaya belajar. Dalam penelitian ini, mengetahui gaya belajar mahasiswa sebagai cara untuk mencari jalan agar belajar menjadi hal yang mudah dan menyenangkan. Sebagaimana diketahui, belajar membutuhkan konsentrasi, situasi dan kondisi. Untuk konsentrasi sangat berhubungan dengan gaya belajar. Jika gaya belajar mahasiswa dikenali, maka pembelajaran dapat dikelola pada kondisi apa, dimana, kapan dan bagaimaa kita dapat memaksimalkan belajarnya. Mengenali gaya belajar belum tentu 
Membuat mahasiswa menjadi lebih pandai, tetapi dengan mengenali gaya belajar dapatditentukan cara belajar yang lebih efektif. Gaya belajar didefinisikan sebagai kebiasaan belajar dimana seseorang merasa paling efisien dan efektif dalam menerima, memproses, menyimpan dan mengeluarkan sesuatu yang dipelajari, (Silberman, M.L. 2010) Berdasarkan penjelasan diatas, maka dilakukan penelitian penerapan model pembelajaran generatif dalam upaya meningkatkan prestasi mahasiswa. Adapun tujuan dalam penelitian ini adalah untuk mengetahui:(1) pengaruh model pembelajaran generatif melalui media riil dan media virtuil terhadap prestasi belajar mahasiswa, (2) pengaruh gaya belajar terhadap prestasi belajar mahasiswa, (3) interaksi antara model pembelajaran generatif dengan media riil dan media virtuil dengan gaya belajar terhadap prestasi belajar mahasiswa.

\section{Metode Penelitian}

Penelitian dilakukan di IKIP PGRI Madiun tahun akademik 2012/2013 yang beralamat di Jalan Setia Budi No. 85Kota Madiun, Provinsi Jawa Timur.Penelitian ini menggunakan metode eksperimen dengan desain faktorial $2 \times 2$. Populasi penelitian adalah seluruh mahasiswa semester I Prodi Biologi IKIP PGRI Madiun, yang terdiri dari 2 kelas yaitu, kelas IA sebagai kelas eksperimen yang diberikan pembelajaran generatif dengan menggunakan media riil dan kelas IB yang diberikan pembelajaran generatif dengan menggunakan media virtuil. Tehnik test digunakan

untuk pengumpulan data hasil belajar kognitif dan psikomotor sedang tehnik non test melalui angket dan lembar observasi. Lembar observasi digunakan untuk mengukur hasil belajar afektif dan psikomotor saat pembelajaran, sedangkan angket juga dipergunakan untuk mengukur prestasi afektif.

Teknik pengumpulan data dalam penelitian ini menggunakan: (1) metode tes untuk mengetahui prestasi belajar kognitif mahasiswa, (2) metode angket digunakan untuk mengetahui gaya belajar, nilai prestasi belajar psikomotorik, dan afektif mahasiswa, (3) metode observasi dilakukan untuk mendapatkan kumpulan data prestasi belajar afektif dan psikomotor saat mahasiswa sedang melakukan proses pembelajaran. Instrumen pelaksanaan penelitian dalam penelitian ini berupa silabus, Rencana Pelaksanaan Pembelajaran (RPP) dan Lembar Kerja Mahasiswa (LKM).Instrumen pengambilan data digunakan tes, angket dan observasi. Tes digunakan untuk mengukur prestasi belajar kognitif mahasiswa. Angket digunakan untuk mengukur gaya belajar, nilai prestasi belajar psikomotorik, dan afektif mahasiswa. Observasi untuk mendukung penilaian afektif dan psikomotor mahasiswa.

Uji normalitas data menggunakan metode Lillieforceyang terdapat pada software SPSS 18. Dan uji homogenitas digunakan adalah uji Barlett. Kemudian Pengujian hipotesis pada penelitian ini menggunakan uji anavadengan bantuan software SPSS 18.

\section{Hasil Penelitian dan Pembahasan}

Deskripsi data untuk kedua kelas eksperimen tersebut dapat dilihat pada Tabel 2.

Tabel 2 Rata-rata Prestasi Belajar Ditinjau dari Media, Gaya belajar

\begin{tabular}{ccccc}
\hline \multirow{2}{*}{ Tinjauan } & \multicolumn{3}{c}{ Prestasi Belajar } \\
\cline { 2 - 5 } & & Kognitif & Afektif & Psikomotor \\
\hline \multirow{2}{*}{ Media } & Riil & 74,00 & 71,31 & 68,14 \\
\cline { 2 - 5 } & Virtuil & 72,00 & 69,40 & 63,89 \\
\hline Gaya & Kinestetik & 72,69 & 70,87 & 64,74 \\
\cline { 2 - 5 } Belajar & Visual & 72,13 & 69,71 & 67,61 \\
\hline
\end{tabular}

Data prestasi belajar kognitif diperoleh dari rata-rata angket, serta tes hasil belajar mahasiswa.Tes hasil belajar kognitif dilakukan setelah semua materi ekosistem selesai diajarkan, dengan jumlah item 40 item soal pilihan ganda.Mahasiswa yang diberi perlakuan pembelajaran generatif melalui media riil memiliki rerata yang lebih tinggi di semua aspek prestasi belajar, dibandingkan dengan rerata mahasiswa yang diberi perlakuan pembelajaran generatif melalui media virtuil.
Mahasiswa yang memiliki gaya belajar kinestetik mempunyai prestasi belajar kognitif dan afektif lebih tinggi dari pada mahasiswa yang memilik gaya belajar visual.

Pengujian hipotesis dengan analisis varian (anava) dua jalan desain faktorial $2 \times 2$ isi sel tidak sama pada taraf sifnifikasi $\alpha=0,05$ menggunakan bantuan software SPSS 18. Keputusan uji jika sig $>0,05$ maka Ho diterima, jika sig < 0,05 maka Ho ditolak.

Tabel 3 Hasil Uji Hipotesis

\begin{tabular}{ccccc}
\hline \multirow{2}{*}{ Hip } & \multirow{2}{*}{ Uji Anava } & \multicolumn{3}{c}{ Aspek } \\
\cline { 3 - 5 } & & Kognitif & Afektif & Psikomotor \\
\hline 1 & Media & 0,023 & 0,024 & 0,011 \\
\hline 2 & Gaya Belajar & 0,021 & 0,031 & 0,000 \\
\hline 3 & Media * Gaya Belajar & 0,810 & 0,896 & 0,385 \\
\hline
\end{tabular}


Berdasarkan Tabel 3 dan kriteria pengujian hipotesis pada uraian diatas, maka pembahasan dari pengujian hipotesis dalam penelitian ini adalah sebagai berikut:

1. Pengaruh Pembelajaran Biologi model generatif melalui media riil dan media virtuil terhadap prestasi belajar mahasiswa.

Berdasarkan hasil uji statistik menunjukkan terdapat perbedaan antara pembelajaran generatif melalui media riil dan media virtuil terhadap prestasi belajar kognitif mahasiswa. Rata-rata prestasi belajar melalui media riil adalah 74,00 sedang kelas yang menggunakan media virtul memiliki rata-rata prestasi belajar 72,00. Hasil tersebut menunjukkan bahwa media riil memberi dampak yang lebih baik daripada media virtuil, karena dalam pembelajaran melalui media riil mahasiswa dapat mengenali langsung obyek-obyek yang diamati.Dengan demikian konsep-konsep yang diperoleh menjadi lebih bermakna dan lebih melekat dalam diri mahasiswa, obyek belajar berupa materi konkrit, nyata, dan ada di lingkungan mahasiswa seharihari.

2. Pengaruh gaya belajar kinestetik dan visual terhadap prestasi belajar mahasiswa.

Berdasarkan hasil analisis menunjukkan bahwa ada perbedaan pengaruh antara gaya belajar kinestetik dan visual terhadap prestasi belajar mahasiswa. Untuk menjawab tentang perbedaan pengaruh gaya belajar kinestetik dan visual terhadap prestasi belajar. Gaya belajar yang dimiliki mahasiswa berbeda-beda, hal ini menyebabkan adanya perbedaan cara mahasiswa dalam menerima dan mengolah informasi. Dalam penelitian ini digunakan media yang memfasilitasi mahasiswa untuk menggali kemampuan dirinya dalam membentuk konsep materi ekosistem, sehingga diharapkan media pembelajaran yang dipakai dapat memberi kontribusi untuk mendapatkan prestasi yang maksimal.

Berdasarkan tabel 2 dapat diketahui bahwa gaya belajar terbagi menjadi 2 kategori yaitu kinestetik dan visual. Berdasarkan mahasiswa yang memiliki gaya belajar kategori kinestetik mendapat nilai rata-rata kognitif, afektif, dan psikomotor lebih besar dari pada mahasiswa yang memiliki gaya belajar kategori visual, jadi mahasiswa yang memiliki gaya belajar kinestetik lebih besar pengaruhnya terhadap prestasi belajar kognitif, afektif, dan psikomotor. Berdasar rerata prestasi belajar tersebut diduga bahwa mahasiswa yang memiliki gaya belajar kinestetik akan lebih menyukai proses pembelajaran dengan media riil daripada media virtuil.

Mahasiswa yang mempunyai gaya belajar kinestetik belajar melalui bergerak, menyentuh, dan melakukan karena keinginan mereka untuk beraktivitas dan eksplorasi sangatlah kuat. Mahasiswa yang bergaya belajar ini belajarnya melalui gerak dan sentuhan sedangkan mahasiswa dengan gaya belajar visual akan lebih mementingkan visualisasi (penglihatan) dalam menyerap materi. Mahasiswa yang mempunyai gaya belajar visual tidak harus melihat bahasa tubuh dan ekspresi muka dosennya untuk mengerti materi pelajaran. Mereka berpikir gambar-gambar di otak mereka dan belajar lebih cepat dengan menggunakan tampilan-tampilan visual, seperti diagram, dan buku pelajaran bergambar.

Menurut hasil penelitian Sandra L Wilson-Hull (2002) dalam jurnal elektronik diungkapkan "when learning styles are addressed, student perform better academically". Jika proses pembelajaran dilakukan denga memperhatikan gaya belajar maka hal tersebut akan meningkatkan prestasi akademik mahasiswa.

3. Interaksi antara model pembelajaran generatif melalui media riil dan media virtuil dengan gaya belajar terhadap prestasi belajar mahasiswa.

Hasil analisis menunjukkan bahwa tidak ada interaksi antara media pembelajaran generatif melalui media riil dan media virtuil dengan gaya belajar terhadap prestasi belajar mahasiswa.

Walaupun tidak ada interaksi antara model pembelajaran dengan gaya belajar mahasiswa, tetapi berdasarkan Tabel 2 bahwa untuk model pembelajaran generatif melalui media riil mempunyai rerata prestasi belajar kognitif dan afektif tertinggi dicapai oleh mahasiswa dengan gaya belajar kinestetik sedangkan untuk model pembelajaran generatif melalui media virtuil rerata prestasi tertinggi juga dicapai oleh mahasiswa dengan gaya belajar kinestetik. Mahasiswa yang memiliki gaya belajar kinestetik akan mempunyai keinginan untuk beraktivitas dan mengeksplorasikan kemampuannya sangat kuat, semakin kuat untuk mencapai prestasi yang lebih tinggi dibandingkan dengan yang memiliki gaya belajar visual yang berbasis penglihatan.

"Gaya belajar merupakan kombinasi bagaimana cara yang dilakukan seseorang dalam menyerap informasi dengan mudah. Dalam hal ini mencakup faktor-faktor fisik, emosional, sosiologis dan kondisi lingkungan. Sehingga gaya belajar dapat mempengaruhi seseorang dalam mengambil langkah-langkah penting dalam diri seseorang untuk bisa belajar lebih cepat dan lebih mudah" (Bobbi DePoter, 2008).

Pada model pembelajaran media virtual mahasiswa dengan gaya belajar kinestetik juga memperoleh hasil yang tinggi, ini dapat dijelaskan mahasiswa yang memiliki gaya belajar kinestetik sangat peka dengan perasaan/emosi dan pada emosi dengan sentuhan dan gerakan mereka juga akan belajar maksimal dalam suatu kondisi dimana banyak keterlibatan fisik dan gerakan. Mahasiswa dengan gaya belajar ini biasanya mengulang 
pelajaran agar ingat dengan pelajaran tersebut melalui latihan-latihan atau aktif di kelas.

\section{Kesimpulan dan Rekomendasi}

Berdasarkan analisis dan pembahasan hasil penelitian dapat dibuat kesimpulan sebagai berikut:(1) Penggunaan model pembelajaran generatif memberikan pengaruh terhadap prestasi belajar kognitif, afektif, dan psikomotor mahasiswa, (2) Gaya belajar memberikan pengaruh terhadap prestasi kognitif, afektif, dan psikomotor mahasiswa, (3) Interaksi antara model pembelajaran generatif melalui media riil dan virtual dengan gaya belajar tidak memberikan pengaruh yang signifikan terhadap prestasi belajar mahasiswa pada aspek kognitif, afektif dan psikomotor.

Hasil penelitian ini memberikan gambaran yang jelas tentang penerapan Model Pembelajaran Generatif menggunakan media riil dan virtuil ditinjau dari gaya belajar mahasiswa pada materi ekosistem.

\section{Rekomendasi}

Pembelajaran menggunakan model generatif melalui media riil dan media virtuil dapat dijadikan alternatif model pembelajaran pada materi ekosistem, karena dapat meningkatkan hasil belajar pada aspek kognitif afektif dan psikomotor. Di dalam pelaksanaan pembelajaran, dosen diharapkan memperhatikan karakteristik materi yang diajarkan agar dapat menerapkan model dan media pembelajaran yang sesuai sehingga didapatkan hasil belajar yang maksimal.Bagi Perguruan Tinggi perlu meningkatkan kompetensi dosen dalam penguasaan berbagai model pembelajaran Biologi. Bagi peneliti lain dapat melakukan penelitian lanjutan dengan menambah/meninjau dari faktor internal lain agar tujuan pembelajaran tercapai dan menghasilkan prestasi belajar yang lebih optimal.

\section{Daftar Pustaka}

Depdiknas.(2005). Peraturan Pemerintah Nomor 19 Tahun 2005 tentang Standar Nasional Pendidika, Jakarta.Biro Hukum dan Organisasi Sekjen Depdiknas.

De Poter, Bobby, Mike. (2008). Quantum Learning (Edisi Terjemahan. Bandung : Mizan Pustaka.

Lily Maysari. (2010). Pembelajaran Fisika dengan Pendekatan Ketrampilan Proses melalui Metode Inkuiri Terbimbing dan Eksperimen ditinjau dari Penalaran Abstrak dan Kemandirian Bernalar Mahasiswa. Tesis. Universitas Sebelas Maret. Surakarta.

Pusporini, S, Ashadi, dan Sarwanto. (2012). Pembelajaran Kimia Berbasis Problem Solving Menggunakan Laboratorium riil dan Virtuil Ditinjau dari Gaya
Belajar dan Kemampuan Berpikir Kritis Siswa.Jurnal Inkuiri I (1), 34 - 43.

Obsorne and Wittrock, 1985.The Generative Learning Model and Its Implications for Science Education.Studies in Science Education.

Sandra L. Wilson-Hull.2008. The Impack of Learning Styles on High Stakes Testing : Perspectives from Mississippi Delta Area Teachers.Alcosn State University. Institute for learning styles journal.

Silberman, M. L. (2010). Active Learning : 101 Cara Belajar Siswa Aktif. Alih Bahasa Raisul Mutaqqin. Bandung: Nusa Media.

Wenno I. H. (2008).Strategi Belajar Mengajar Sains Berbasis Konstektual.Yogyakarta : Inti Media. 